TITLE:

\title{
NOTES ON THE BIOLOGY AND DISTRIBUTION OF THE AEOLID NUDIBRANCH (GASTROPODA), PHESTILLA MELANOBRACHIA BERGH, 1874
}

\section{$\operatorname{AUTHOR}(\mathrm{S})$ :}

Harris, Larry G.

\section{CITATION:}

Harris, Larry G.. NOTES ON THE BIOLOGY AND DISTRIBUTION OF THE AEOLID

NUDIBRANCH (GASTROPODA), PHESTILLA MELANOBRACHIA BERGH, 1874.

PUBLICATIONS OF THE SETO MARINE BIOLOGICAL LABORATORY 1968, 16(3): 193-198

\section{ISSUE DATE:}

1968-11-20

URL:

http://hdl.handle.net/2433/175544

RIGHT: 


\title{
NOTES ON THE BIOLOGY AND DISTRIBUTION OF THE AEOLID NUDIBRANCH (GASTROPODA), PHESTILLA MELANOBRACHIA BERGH, 1874
}

\author{
LARRY G. HARRIS \\ Zoology Department, University of California, Berkeley
}

With 2 Text-Figures

The aeolid nudibranch, Phestilla melanobrachia, was first described by BERGH in 1874 from specimens collected by dredge in the Philippine Sea. Other than the original description, Phestilla melanobrachia has only been reported from Hawaii, where a specimen was figured in Reef and Shore Fauna of Hawaii by Edmondson in 1937. He described it as an unidentified orange aeolid nudibranch associated with the ahermatypic coral, Dendrophyllia manni, now reclassified as Tubastraea aurea (p. 184).

The author has studied the association between Phestilla and its dendrophyllid coral prey from January to July of 1967 at the Hawaii Institute of Marine Biology under the auspices of the East-West Center.

Besides mentioning several interesting aspects of this nudibranch's biology such as its use of coral pigments for coloration and possible defensive mechanisms, the purpose of this paper is to report the collection of $P$. melanobrachia for the first time in Japan, Okinawa and Singapore, and for the second time in the Philippines.

In Hawaii, Phestilla feeds on and can be consistently collected from two species of ahermatypic corals in the family Dendrophylliidae, at depths ranging from two meters to thirty meters.

This relatively large $(40 \mathrm{~mm})$ nudibranch is somewhat flattened dorso-ventrally and has quite a broad foot (about 1/3 of its length). See Figure 1. The tentacles and rhinophores are about $1 / 4$ of its length and smooth. The dorsal papillae or cerata are long and round in cross section and are arranged on ridges which run on a diagonal anterior to posterior. In an adult there are about 15 such rows on each side of the body. The number of papillae per ridge ranges from 12 to 15 near the mid-region of the body to only one at the tail. Although the nudibranch is most often orange in color it can also be in various shades of related colors such as brown or pink depending upon what it has been feeding on. See Figures 1 and 2.

In Hawaii, Phestilla can be collected on the bright orange colonial coral, Tubas-

1) Contributions from the Seto Marine Biological Laboratory, No. 491.

Publ. Seto Mar. Biol. Lab., XVI (3), 193-198, 1968. (Article 14) 
traea aurea, growing most commonly at a depth of 2 to 10 meters. At a depth of 20 to 30 meters it feeds primarily on the red-orange coral, Rhizopsammia serpentina. Phestilla will also feed on the green-black Tubastraea diaphana, and on the pink $T$. coccinea, though this has been only rarely observed in the field.

Bergh described Phestilla melanobrachia as having dark colored cerata, while EDMONDSON describes the same species as being orange. As can be seen in Figures 1 and 2, both of these descriptions apply depending on the individual nudibranch collected. Field observations and laboratory experiments using spectrophotometry and paper chromatography suggest that the nudibranch utilizes the coral pigments (carotenoids as well as other as-yet unidentified pigments) in its own coloration.

The pigments in the coral tissue eaten by the nudibranch are first taken up in the digestive gland which, in aeolids, is located predominantly in the cerata. Only the orange pigment goes into the tissue of the foot as well as into the tissue of the cerata, while the green-black pigment remains exclusively in the cerata. The pigments in the digestive gland are constantly replaced so that if a Phestilla feeds on a greenblack coral after having eaten an orange coral the color of the cerata will slowly change from orange to green-black and conversely. However, the pigmentation of the foot is quite permanent so that an orange nudibranch will retain the orange color in the foot while only the cerata change, and a green-black Phestilla, which has no pigment in the foot, can change completely to orange.

Another interesting aspect of the biology of $P$. melanobrachia is the fact that it does not store nematocysts as do most aeolids. Instead, there are a group of large vacuolated cells at the tip of cerata where a cnidosac would be found in other aeolid nudibranchs. When the cerata are disturbed, they exude droplets of a clear viscous material which dissolve very slowly in sea water. It seems likely that these secretions are defensive in function as suggested by EDMunds in 1966 regarding secretory glands in the cerata of other aeolid species.

In September of 1967 the author traveled to Singapore to collect and study Phestilla melanobrachia and its associated dendrophyllid corals. Visits were made along the way to the Seto Marine Biological Laboratory in Japan, the Ryukyu University in Okinawa, and to the Mindanao State University in the Philippines. It was the author's intention to scuba-dive for Phestilla in each of these localities in order to learn something of its distribution and compare habitats.

Specimens of Phestilla melanobrachia were collected in each area. These are the first reports of this nudibranch in Japan, Okinawa and Singapore, and the first report since 1874 in the Philippines. Collection data as follows:

Seto Marine Biological Laboratory, Shirahama, Japan

18 September 1967: Four Phestilla melanobrachia $(5 \mathrm{~mm}$ to $10 \mathrm{~mm}$ ) were found on a partially eaten colony of Tubastraea aurea. The coral was located on the ceiling of a small cave in about 3 meters of water and was one of a great concentration of $T$. aurea. The cave was on the seaward side of the islet of Toshima. 


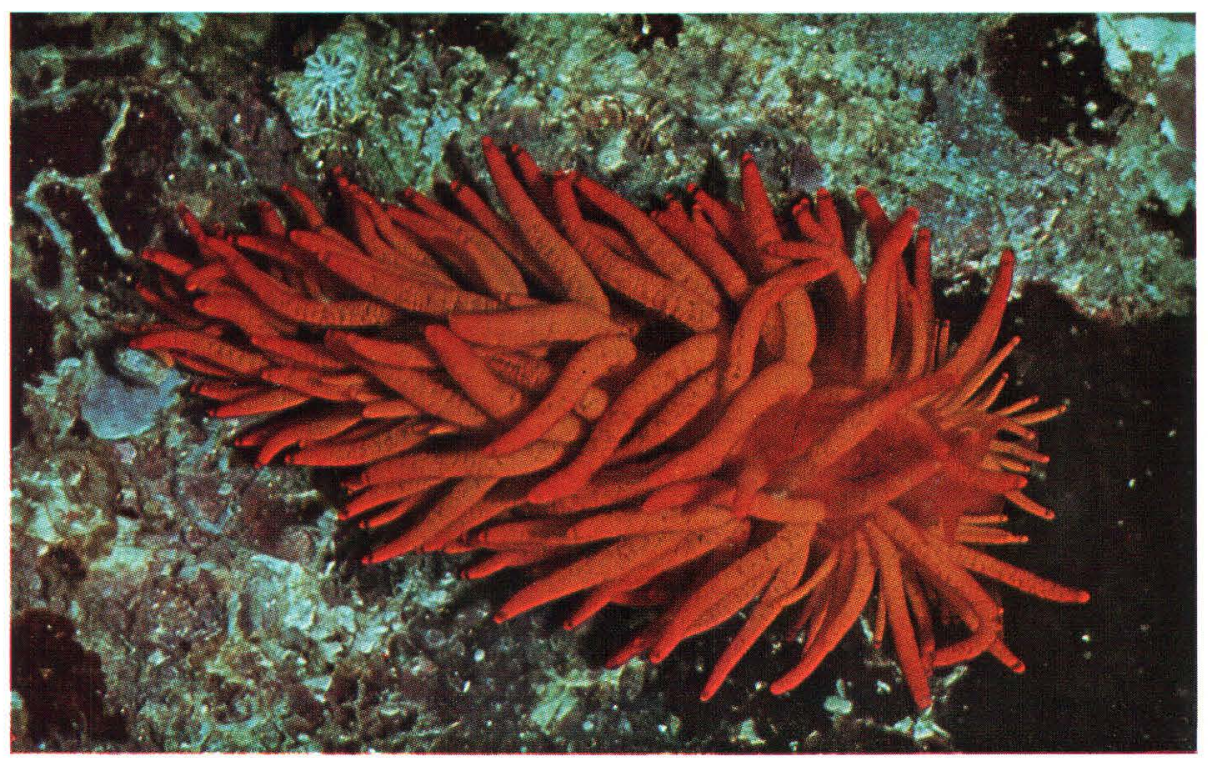

Fig. 1. Phestilla melanobrachia Bergh, orange individual feeding on Tubastraea aurea, Singapore.

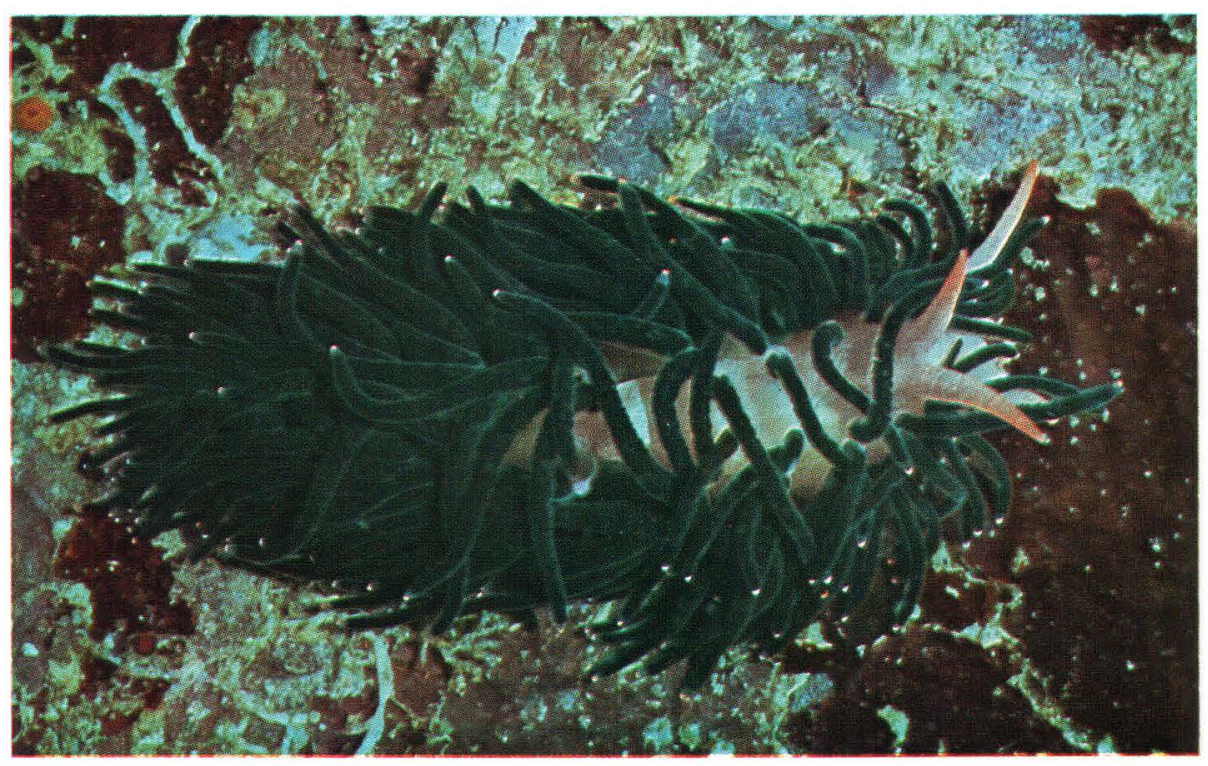

Fig. 2. Phestilla melanobrachia BERGH, black individual feeding on Tubastraea diaphana, Singapore. 
19 September 1967: Four P. melanobrachia $(3 \mathrm{~mm}$ to $5 \mathrm{~mm}$ ) were collected separately on small colonies ( 1 to 3 polyps each) of Tubastraea aurea on the landward side of the island of Shisôjima at depths from 1 to 4 meters.

\section{Onna, Okinawa}

28 September 1967: Two P. melanobrachia (20 mm and $8 \mathrm{~mm}$ ) were found on separate colonies of $T$. aurea on the reef immediately south of Ebu Beach. Concentrations of Tubastraea were found in 1 to 3 meters of water in narrow channels just before the outer edge of the reef flat. The large Phestilla was on a completely eaten colony of coral and five egg masses were present. The small nudibrandh was hidden in a polyp which had been eaten away. This is a typical position for small $P$. melanobrachia.

\section{Zamboanga, Philippines}

10 October 1967: Two Phestilla melanobrachia $(25 \mathrm{~mm}$ and $5 \mathrm{~mm}$ ) were collected on separate colonies of Tubastraea aurea from large dead coral heads on the northern side of Little Santa Cruz Island. The larger specimen was on an almost clean colony of $T$. aurea while the smaller one was in an eaten polyp of an otherwise intact colony. This particular area is at the edge of a deep channel with fast moving tidal currents of up to 6 knots. The many large dead coral heads are in 3 to 10 meters and contain as many as eight species of dendrophyllid corals with $T$. aurea on the upper exposed area and the others growing in crevices and undercuts below.

11 October 1967: Three P. melanobrachia $(7 \mathrm{~mm}, 9 \mathrm{~mm}$ and $15 \mathrm{~mm}$ ) were found on pieces of living coral which were lying on the bottom below a rocky undercut whose ceiling was covered densely with dendrophyllid corals. This ledge is located in 4 meters of water northwest of the village on the northern shore of Coco Island which is approximately 10 miles southeast of Zamboanga. The smallest Phestilla was hidden in an eaten polyp of a colony of Tubastraea aurea that was lying upside down on the bottom. The other two animals were found together on a colony of pink Dendrophyllia $\mathrm{sp}$. which had also fallen to the bottom.

12 October 1967: One $P$. melanobrachia $(4 \mathrm{~mm})$ was collected in a partially eaten polyp of a Tubastraea aurea colony which was found upside down on the bottom below a large concentration of $T$. aurea on an undercut rock. This area is on the sheltered side of a small islet at the western end of Coco Island. Channels and undercut ledges are numerous and Tubastraea is one of the dominant colonial animals in the area with many colonies reaching 30 centimeters in diameter.

Raffles Lighthouse, Singapore

Phestilla melanobrachia can be collected consistently on Tubastraea aurea and $T$. diaphana at depths ranging from 1 meter to 20 meters. These two corals, along with about five other species of dendrophylliid corals which have not yet been identified, are quite common on several of the small islands immediately south of Singapore. 
Of the Phestilla melanobrachia collected in Singapore about $40 \%$ are found on the greenblack Tubastraea diaphana. This does not conform to collecting data from other areas, however, $T$. diaphana is also more common than $T$. aurea at depths below 5 meters here in Singapore.

The association between Phestilla melanobrachia and the ahermatypic corals $T$. aurea and $T$. diaphana seems to be consistent throughout an extensive area of the Pacific. Their presence in Japan, Okinawa, the southern Philippines and Singapore would seem to indicate that this association will occur under suitable conditions in most other areas of the western Pacific. The fact that the same association occurs in Hawaii indicates that it probably also occurs in at least some of the middle Pacific island groups as well. In fact, it seems likely that $P$. melanobrachia will be found to occur almost anywhere that Tubastraea aurea is common.

\section{Summary}

1. The association between the aeolid nudibranch, Phestilla melanobrachia Bergh 1874, and three species of two ahermatypic coral genera, Dendrophyllia and Tubastraea, in the western Pacific is described.

2. Preliminary studies suggest that this nudibranch is capable of utilizing the pigments of its coral prey directly with little or no chemical modification.

3. P. melanobrachia does not store nematocysts, but instead secretes a clear viscous material from the tips of its cerata. This material appears to be defensive in function.

4. The range of distribution of $P$. melanobrachia is now extended to include Japan, Okinawa and Singapore, as well as Hawaii and the Philippines. Ecological data concerning each nudibranch collected and the habitat of the corals are reported.

\section{Acknowledgements}

The author would like to thank Dr. Kikutarô BABA of the Biological Laboratory at Osaka Kyoiku University in Japan for identifying the nudibranch as Phestilla melanobrachia, and Dr. Huzio UTINom of the Seto Marine Biological Labroatory in Japan who identified the dendrophylliid corals from Hawaii and Japan.

The author is also grateful to the many people at the Hawaii Institute of Marine Biology, Seto Marine Biological Laboratory in Japan, Ryukyu University in Okinawa, Mindanao State University in the Philippines and the members of the University of Singapore Zoology Department who have been extremely hospitable and helpful in providing him with the necessary laboratory space and equipment as well as field collection information. They have all contributed to making his study a success.

And finally, he would like to express his appreciation to the East-West Center in Hawaii for the fellowship which is supporting this field research trip. 


\section{LITERATURE CITED}

Bergh, R., 1874. Neue Nacktschnecken der Südsee. II. Journal des Museum Godeffroy, Heft VI, pp. 91-95, Taf. II, Fig. 1-14.

1905. Die Opisthobranchiata der Siboga Expedition. E.J. Brill, Leiden, 248 pp., 20 pls.

Edmondson, C.H., 1933. Reef and Shore Fauna of Hawait. Bernice P. Bishop Museum, Special Publication 22, Honolulu, Hawaii, 295 pp. 